\title{
Mineral Composition and Dry Mass Production of the Corn Plants in Response to Phosphorus Sources and Aluminum Concentration
}

\author{
Marcelo Augusto Batista ${ }^{1^{*}}$, José Carlos Pintro ${ }^{1}$, Antonio Carlos Saraiva da Costa ${ }^{1}$, Cássio \\ Antonio Tormena ${ }^{1}$, Carlos Moacir Bonato ${ }^{2}$ and Michelli Fernandes Batista ${ }^{1}$ \\ ${ }^{I}$ Departamento de Agronomia; Universidade Estadual de Maringá; Maringá - PR - Brasil. ${ }^{2}$ Departamento de \\ Biologia; Universidade Estadual de Maringá; 87020-900; Maringá - PR - Brasil
}

\begin{abstract}
The corn plants were evaluated with different phosphate fertilizer sources and aluminum (Al) concentrations in a sandy substrate. A totally randomized experiment design was set up with two corn plants in the pots containing $2 \mathrm{~kg}$ of a sandy substrate, two phosphate sources (Triple Super Phosphate - TSP or Arad Phosphate - AP) and four Al concentrations. When Al concentrations increased, $\mathrm{pH}\left(\mathrm{CaCl}_{2}\right)$ substrate values decreased. There was an increase in the calcium and phosphorus contents in the sandy substrates that received the TSP and AP sources. The calcium, magnesium, phosphorus, and potassium concentrations of the corn plant's shoot were higher in the TSP than without $P$ and AP sources. When the Al concentration increased, the concentration values of the former elements decreased. The dry mass production of the corn plants responded positively to P sources. As the Al concentration increased, the dry mass values decreased significantly in the TSP source.
\end{abstract}

Key words: Zea mays, phosphate fertilizers, solubility, toxicity

\section{INTRODUCTION}

The soils in the tropical region are usually acidic and contain high $\mathrm{Al}$ values and phosphorus deficiency (Sanchez and Salinas, 1981). When productivity is taken into account, the low response of the th crops to the fertilizers is largely due to the toxic levels of aluminum $(\mathrm{Al})$ in the soil (Calbo and Cambraia, 1980). Al toxicity has been recognized, for a long time, as the main limiting factor of the plant growth in the acidic soils (Hartwell and Pember, 1918; Magistad, 1925). Al reduces the plant development as a whole (Randall and Vose, 1963; Costa et al., 2003) and interferes with the root elongation (Matsumoto and Morimura, 1980), nutrients' uptake, transport and use (e.g. phosphorus - P) (McCormick and Borden, 1972; Adrew and Berg, 1973; McCormick, 1974; Fleming, 1983). Al toxicity effects have been associated with the $P$ accumulation in the root system and low contents in the plant shoot, where the plants may show mineral deficiency symptoms (Macklon and Sim, 1992). Al precipitates with the $\mathrm{P}$ in the apoplastic root compartment and reduces its translocation to the shoot (Calbo and Cambraia, 1980). Interaction

\footnotetext{
* Author for correspondence: batistamar@hotmail.com
} 
may occur both in the cell wall and externally in the plasma membrane of the root cap cells (McCornmick and Borden, 1972) or internally in the vacuole of the roots cells (Macklon and Sim, 1992). In addition, Al may reduce the solubility of $\mathrm{P}$ compounds in the external solution near the roots while it becomes less available to the plants (Pavan and Bingham, 1982; Camargo, 1985).

The interactions between the $\mathrm{P}$ and $\mathrm{Al}$, which affect plant growth in acid soil conditions, have been studied by several authors. For example, high levels of the P fertilizers may reduce the effects of Al toxicity owing to the formation of complexes with low chemical activity (Alva et al., 1986).

The efficiency of the phosphate fertilizers depends on different factors related to their intrinsic characteristics, soil properties, management practices and plant characteristics (Khasawneh and Doll, 1978; Chien and Menon, 1995; Rajan et al., 1996). One of the commercial classifications of the phosphate fertilizers is their solubility in the water. For instance, Triple Super Phosphate (TSP) presents high water solubility, an Arad Phosphate (AP) shows low water solubility (Malavolta, 1981). These differences may affect uptake of the P by the plant (Goedert et al., 1986; Goedert and Souza, 1984). Recently, Pintro et al. (2004) working with the clayey soil in different $\mathrm{P}$ sources (TSP, AP and Tricalcium Phosphate) and Al saturation levels $(86,29$ and $0 \%$ ) observed the alterations in the corn dry mass production, soil and plant chemical attributes.

This work evaluated the influence of different phosphate fertilizer sources and levels of Al on dry mass production and mineral composition of the corn plants in a greenhouse experiment.

\section{MATERIAL AND METHODS}

The substrate was basically composed of sandy dried at the room temperature, sifted ( $2 \mathrm{~mm}$-mesh) and homogenized. The substrate samples were collected for the physical and chemical analysis (Embrapa, 1997).

The experimental design consisted of totally randomized factorial block with three sources of the $\mathrm{P} x$ four $\mathrm{Al}$ concentrations and four replicates. The analysis of variance used Tukey's test to determine the statistical significance at $5 \%$ probability by the SAS software (SAS Institute, 1991).
Two sources of $\mathrm{P}$ were tested: Triple Super Phosphate (TSP) and Arad Phosphate (AP). A single $\mathrm{P}$ dose of $150 \mathrm{mg} \mathrm{kg}^{-1}$ and an additional treatment without the $\mathrm{P}$ (WP) were used. $\mathrm{Al}$ solution prepared from the $\mathrm{AlCl}_{3} \cdot 6 \mathrm{H}_{2} \mathrm{O}$ p.a. was applied to the substrate at four different doses: 0, 25, 50 and $100 \mathrm{mg} \mathrm{kg}^{-1}$ substrate. Four corn seeds (hybrid AS-3477) were sown per pot ( $2 \mathrm{~kg}$ of substrate). Twelve days after the emergence, the plants were thinned to two uniformly-sized plants per pot. The substrate was fertilized by a basic nutrient solution with the following composition: $\mathrm{N}=150 ; \mathrm{K}=150$; $\mathrm{S}=38 ; \mathrm{Ca}=75 ; \mathrm{Mg}=38 ; \mathrm{Mo}=0.11 ; \mathrm{Zn}=3$; $\mathrm{B}=0.61 ; \mathrm{Cu}=1 ; \mathrm{Fe}=1.16 \mathrm{mg} \mathrm{kg}^{-1}$ substrate (NOVAIS et al., 1991) split in three applications (5, 10 and 20 days). The experimental units were irrigated with the distilled water, when necessary. The plants were harvested after 35 days; the roots and shoots were separated; dried to constant weight at $70^{\circ} \mathrm{C}$, and weighed. The samples of the plant's dry mass were chemically analyzed according to Malavolta et al. (1997). At the same time, the substrate samples were collected, dried, sifted and submitted to the same chemical analysis of the original substrate, following Embrapa (1997).

\section{RESULTS AND DISCUSSION}

Results of the particle size distribution were: sand $=880$; silt $=10$; clay $=110 \mathrm{~g} \mathrm{~kg}^{-1}$. The chemical analysis results were: $\mathrm{pH}$ in $\mathrm{CaCl}_{2} 0.01 \mathrm{~mol} \mathrm{~L}^{-1}$ $(1: 2.5)=6.1 ; \mathrm{P}=4 \mathrm{mg} \mathrm{dm}^{-3} ;$ organic carbon $=$ $0.36 \mathrm{~g} \mathrm{dm}^{-3} ; \mathrm{H}^{+}+\mathrm{Al}^{3+}=1.49 ; \mathrm{Al}^{3+}=0 ; \mathrm{Ca}^{2+}+$ $\mathrm{Mg}^{2+}=1.49 ; \mathrm{Ca}^{2+}=1.14 ; \mathrm{K}^{+}=0.03 \mathrm{cmol}_{\mathrm{c}} \mathrm{dm}^{-3}$; sum of bases $\left(\mathrm{SB}=\mathrm{Ca}^{2+}+\mathrm{Mg}^{2+}+\mathrm{K}^{+}\right)=1.52$ $\mathrm{cmol}_{\mathrm{c}} \mathrm{dm}^{-3}$ and cation exchange capacity $(\mathrm{CEC}=$ $\left.\mathrm{SB}+\mathrm{H}^{+}+\mathrm{Al}^{3+}\right)=3.01 \mathrm{cmol}_{\mathrm{c}} \mathrm{dm}^{-3}$.

Table 1 shows the substrate's chemical analysis after the experimental period. The $\mathrm{pH}\left(\mathrm{CaCl}_{2}\right)$ values decreased in proportion to an increase in the $\mathrm{Al}$ concentration values in the WP and in the TSP sources. Pintro et al. (2004), working with a clayey soil observed similar results. The AP source also presented some variations but statistical difference $(P<0.05)$ was only observed in the treatment with the highest $\mathrm{Al}$ dose $\left(100 \mathrm{mg} \mathrm{kg}^{-1}\right)$. When the $\mathrm{P}$ 
sources were mutually compared, $\mathrm{pH}$ values were significantly higher in the WP source than in the AP or in the TSP source at the $\mathrm{Al} 0$ and $25 \mathrm{mg} \mathrm{kg}^{-1}$ concentrations (Table 1). Regarding the Al, the TSP source had a higher acidification process than that of the AP source. The same behavior was not observed (Pintro et al., 2004) for the same P sources (TSP and AP) when the substrate had higher buffer capacity due to the presence of the organic matter and iron oxides (Novais and Smyth, 1999). Taking the TSP source into account, the acidification process has also been reported by Malavolta (1981) and Ernani et al. (2001).

For the same $\mathrm{P}$ source, no significant differences $(P<0.05)$ in the $\mathrm{Ca}$ concentrations values in the substrate were reported as the Al concentration increased (Table 1). Since they have $\mathrm{Ca}$ in their chemical compositions $(14 \%$ and $20 \%$, respectively), Ca numerical values in the substrate were higher and/or significantly higher in the TSP and AP sources than in the WP treatment (COAMO, 1998).

$\mathrm{Mg}$ values in the substrate were not affected by the $\mathrm{P}$ sources and $\mathrm{Al}$ concentration. An exception was noted in the TSP source at $100 \mathrm{mg} \mathrm{kg}^{-1}$ of $\mathrm{Al}$, where the $\mathrm{Mg}$ value was significantly higher $(P<0.05)$ than that in WP (Table 1).

$\mathrm{K}$ values in the substrate, fertilized with the TSP source, increased with the Al doses (Table 1). This variation was related to the dry mass production of the corn plants which, in the TSP source, was inversely related to the $\mathrm{Al}$ dose applied to the substrate. In the AP source, the $\mathrm{K}$ values in the substrate decreased with an increase in the $\mathrm{Al}$ doses. The highest numerical $\mathrm{K}$ value in the substrate with the AP source was observed in the treatment without $\mathrm{Al}$, followed by 25,100 and 50 $\mathrm{mg} \mathrm{Al} \mathrm{kg}{ }^{-1}$ dose treatments. When the P sources in the same $\mathrm{Al}$ dose were compared, the 0 and $25 \mathrm{mg}$ $\mathrm{kg}^{-1}$ doses revealed similar decreasing order of the $\mathrm{K}$ values, AP $<\mathrm{WP}<\mathrm{TSP}$. No statistical difference existed between the $\mathrm{K}$ concentrations in $\mathrm{P}$ sources in the remaining $\mathrm{Al}$ doses (50 and 100 $\mathrm{mg} \mathrm{kg}^{-1}$ ). The AP had high $\mathrm{Ca}$ and $\mathrm{Mg}$ concentrations (20 and 15\%, respectively) which were important to $\mathrm{K}$ absorption dynamics. With regard to the lowest $\mathrm{Al}$ doses $\left(0\right.$ and $\left.25 \mathrm{mg} \mathrm{kg}^{-1}\right)$, $\mathrm{Ca}$ and $\mathrm{Mg}$ values, observed in the AP source, might have influenced the negative $\mathrm{K}$ absorption.

The $\mathrm{P}$ values in the substrate were not affected by the $\mathrm{Al}$ concentrations. However, $\mathrm{P}$ values in the same $\mathrm{Al}$ concentration were significantly higher in the TSP and AP sources than in the WP treatment (Table 1) (Pintro et al. 2004). Although there was no significant difference between the TSP and AP sources, except at $50 \mathrm{mg} \mathrm{kg}^{-1}$ of the $\mathrm{Al}$, in which the AP source was significantly higher than that in the TSP (Ernani et al. 2001). A higher P value availability in the substrate which received the AP source could be justified by the fact that the $\mathrm{P}$ was analyzed by means of an acid extractor, i.e. Mehlich-1 $\left(\mathrm{HCl} 0.05 \mathrm{~N}+\mathrm{H}_{2} \mathrm{SO}_{4} 0.025 \mathrm{~N}\right)$ which dissolved calcium phosphate particles present in the AP fertilizer, and thus overestimated the $\mathrm{P}$ availability to the plants (Ernani et al., 2001).

Table 1 - Substrate Chemical Analysis Where Corn Plants Were Cultivated for 35 Days Using Different Phosphate Sources and Aluminum (Al) Concentrations.

\begin{tabular}{|c|c|c|c|c|c|}
\hline \multirow{2}{*}{ Variable } & \multirow{2}{*}{ P Source } & \multicolumn{4}{|c|}{ Al concentrations $\left(\mathrm{mg} \mathrm{kg}^{-1}\right)$} \\
\hline & & $\mathbf{0}$ & 25 & 50 & 100 \\
\hline \multirow[t]{3}{*}{$\mathrm{pH} \mathrm{CaCl}{ }_{2}$} & WP & $6.60 \mathrm{aA}$ & $6.33 \mathrm{aA}$ & $5.80 \mathrm{bB}$ & $4.77 \mathrm{cC}$ \\
\hline & TSP & $6.27 \mathrm{aB}$ & $6.00 \mathrm{abB}$ & $5.87 \mathrm{bAB}$ & $5.30 \mathrm{cB}$ \\
\hline & $\mathrm{AP}$ & $5.93 \mathrm{abC}$ & $6.20 \mathrm{aAB}$ & $6.07 \mathrm{aA}$ & $5.73 \mathrm{bA}$ \\
\hline \multirow{3}{*}{$\begin{array}{c}\mathrm{Ca} \\
\left(\mathrm{cmol}_{\mathrm{c}} \mathrm{dm}^{-3}\right)\end{array}$} & WP & $1.49 \mathrm{aA}$ & $1.41 \mathrm{aB}$ & $1.45 \mathrm{aB}$ & $1.36 \mathrm{aB}$ \\
\hline & TSP & $1.88 \mathrm{aA}$ & $2.07 \mathrm{aA}$ & $1.84 \mathrm{aAB}$ & $2.10 \mathrm{aA}$ \\
\hline & $\mathrm{AP}$ & $1.90 \mathrm{aA}$ & $1.78 \mathrm{aAB}$ & $2.04 \mathrm{aA}$ & $1.93 \mathrm{aA}$ \\
\hline \multirow{3}{*}{$\begin{array}{c}\mathrm{Mg} \\
\left(\mathrm{cmol}_{\mathrm{c}} \mathrm{dm}^{-3}\right)\end{array}$} & WP & $0.54 \mathrm{aA}$ & $0.50 \mathrm{aA}$ & $0.48 \mathrm{aA}$ & $0.43 \mathrm{aB}$ \\
\hline & TSP & $0.52 \mathrm{aA}$ & $0.62 \mathrm{aA}$ & $0.54 \mathrm{aA}$ & $0.61 \mathrm{aA}$ \\
\hline & $\mathrm{AP}$ & $0.56 \mathrm{aA}$ & $0.54 \mathrm{Aa}$ & $0.61 \mathrm{aA}$ & $0.57 \mathrm{aAB}$ \\
\hline \multirow{3}{*}{$\begin{array}{c}\mathrm{K} \\
\left(\mathrm{cmol}_{\mathrm{c}} \mathrm{dm}^{-3}\right)\end{array}$} & WP & $0.26 \mathrm{aB}$ & $0.21 \mathrm{aAB}$ & $0.22 \mathrm{aA}$ & $0.18 \mathrm{aA}$ \\
\hline & TSP & $0.10 \mathrm{bC}$ & $0.13 \mathrm{bB}$ & $0.16 \mathrm{abA}$ & $0.28 \mathrm{aA}$ \\
\hline & $\mathrm{AP}$ & $0.40 \mathrm{aA}$ & $0.26 \mathrm{bA}$ & $0.20 \mathrm{bA}$ & $0.25 \mathrm{bA}$ \\
\hline \multirow{3}{*}{$\begin{array}{c}\mathrm{P} \\
\left(\mathrm{mg} \mathrm{dm}^{-3}\right)\end{array}$} & WP & $4.00 \mathrm{aB}$ & $4.33 \mathrm{aB}$ & $4.00 \mathrm{aC}$ & $4.33 \mathrm{aB}$ \\
\hline & TSP & $133 \mathrm{aA}$ & $154 \mathrm{aA}$ & $137 \mathrm{aB}$ & $241 \mathrm{aA}$ \\
\hline & $\mathrm{AP}$ & $218 \mathrm{aA}$ & $211 \mathrm{aA}$ & $264 \mathrm{aA}$ & $283 \mathrm{aA}$ \\
\hline
\end{tabular}

Means followed by the same upper-case letter (vertical) and lower-case letter (horizontal) indicate no significance at 5\% of probability (Tukey test). (WP - without P; TSP - Triple superphosphate; AP - Arad Phosphate) 
Table 2 presents the amount of the mineral elements in the plant's shoot. Although the $\mathrm{Al}$ levels increased, no significant difference in the $\mathrm{Ca}$ and $\mathrm{Mg}$ values in the WP treatment occurred. On the other hand, with the increasing $\mathrm{Al}$ doses, the $\mathrm{Ca}$ and $\mathrm{Mg}$ values in the shoot of the corn plant in TSP source were significantly reduced (Table 2). With regard to the AP source, the $\mathrm{Ca}$ and $\mathrm{Mg}$ values were significantly higher in the treatments with the $\mathrm{Al}$ than in those without it.

With the increasing $\mathrm{Al}$ concentrations in the substrate, a significant reduction occurred in the $\mathrm{P}$ amount in the shoot of the corn plant's shoot, albeit only in the TSP source (Table 2). When the $\mathrm{P}$ sources were compared at the same $\mathrm{Al}$ concentration level, the $\mathrm{P}$ values in the shoot were higher in the TSP source than in the control (WP) or AP source. Significant reduction in the P values in the shoot of the corn plant's shoot on the increase of the $\mathrm{Al}$ concentration in the substrate could be justified by the formation of the low solubility compounds between P from TSP and Al in the substrate and/or on the surface of the corn plant's roots (Helyar, 1978; Calbo and Cambraia, 1980; Roy et al., 1994).

As the $\mathrm{Al}$ concentration increased in the substrate, the $\mathrm{K}$ values in the shoot of the corn plant failed to decrease significantly in the treatment without the $\mathrm{P}$ (WP) (Table 2). On the other hand, when the concentrations were 50 and $100 \mathrm{mg} \mathrm{kg}^{-1}$ in the TSP source, the $K$ values were significantly lower than the $\mathrm{Al}$ concentrations 0 and $25 \mathrm{mg} \mathrm{kg}^{-1}$. It could be noted that in the AP source, the $\mathrm{K}$ values in the shoot of the corn plant were higher with the Al than without it. When the $\mathrm{P}$ sources were compared, the $\mathrm{K}$ values in the shoot were higher in the TSP than in the WP and AP source, except at the $\mathrm{Al}$ concentration $100 \mathrm{mg} \mathrm{kg}^{-1}$, where the AP source showed the highest values.

Table 2 - Mineral Composition of Corn Plant Shoot Cultivated for 35 Days Using Different Phosphate Sources and Aluminum (Al) Concentrations.

\begin{tabular}{clcccc}
\hline $\begin{array}{c}\text { Variable } \\
\left(\text { mg pot }^{-1}\right)\end{array}$ & P Source & \multicolumn{4}{c}{ Al concentrations $\left(\mathbf{m g ~ k g}^{-1}\right)$} \\
\cline { 3 - 6 } & & $\mathbf{0}$ & $\mathbf{2 5}$ & $\mathbf{5 0}$ & $\mathbf{1 0 0}$ \\
\hline $\mathrm{Ca}$ & $\mathrm{WP}$ & $7.71 \mathrm{aB}$ & $9.36 \mathrm{aB}$ & $6.52 \mathrm{aB}$ & $3.86 \mathrm{aA}$ \\
& TSP & $64.63 \mathrm{aA}$ & $43.68 \mathrm{abA}$ & $35.58 \mathrm{bcA}$ & $15.07 \mathrm{cA}$ \\
& $\mathrm{AP}$ & $11.84 \mathrm{bB}$ & $34.08 \mathrm{aA}$ & $29.54 \mathrm{abA}$ & $23.33 \mathrm{abA}$ \\
\hline $\mathrm{Mg}$ & $\mathrm{WP}$ & $2.09 \mathrm{aB}$ & $2.05 \mathrm{aB}$ & $1.55 \mathrm{aB}$ & $0.67 \mathrm{aB}$ \\
& TSP & $14.28 \mathrm{aA}$ & $10.09 \mathrm{bA}$ & $8.73 \mathrm{bA}$ & $2.96 \mathrm{cAB}$ \\
& $\mathrm{AP}$ & $3.10 \mathrm{bB}$ & $7.25 \mathrm{aA}$ & $6.85 \mathrm{abA}$ & $4.99 \mathrm{abA}$ \\
\hline $\mathrm{P}$ & $\mathrm{WP}$ & $0.30 \mathrm{aB}$ & $0.29 \mathrm{aB}$ & $0.28 \mathrm{aB}$ & $0.28 \mathrm{aB}$ \\
& TSP & $40.44 \mathrm{aA}$ & $35.01 \mathrm{abA}$ & $26.56 \mathrm{bA}$ & $8.94 \mathrm{cA}$ \\
& AP & $0.57 \mathrm{aB}$ & $2.89 \mathrm{aB}$ & $5.02 \mathrm{aB}$ & $2.91 \mathrm{aAB}$ \\
\hline $\mathrm{K}$ & $\mathrm{WP}$ & $15.75 \mathrm{aB}$ & $19.57 \mathrm{aC}$ & $14.18 \mathrm{aB}$ & $6.30 \mathrm{aB}$ \\
& $\mathrm{TSP}$ & $151.68 \mathrm{aA}$ & $124.36 \mathrm{abA}$ & $95.24 \mathrm{bA}$ & $37.36 \mathrm{cAB}$ \\
& AP & $21.34 \mathrm{bB}$ & $73.93 \mathrm{aB}$ & $78.75 \mathrm{aA}$ & $61.26 \mathrm{aA}$ \\
\hline
\end{tabular}

Means followed by the same upper-case letter (vertical) and lower-case letter (horizontal) indicate no significance at 5\% of probability (Tukey test). (WP - without P; TSP - Triple superphosphate; AP - Arad Phosphate).

The corn shoot's dry mass production in the WP substrate was not affected by the $\mathrm{Al}$ concentrations (Fig. 1A). Otherwise, the increment of the $\mathrm{Al}$ determined high inhibition rate in the shoot growth when the TSP source was used. The TSP-treated plants presented higher nutrient concentrations values, with the exception of $\mathrm{Mg}$ at $100 \mathrm{mg} \mathrm{kg}^{-1}$. On the other hand, as the $\mathrm{Al}$ concentration increased in the TSP source, the shoot's dry mass values decreased significantly.

In the case of the AP source, since $\mathrm{Al}$ concentration ranged from 25 to $50 \mathrm{mg} \mathrm{kg}^{-1}$ in the substrate, the shoot dry mass production increased significantly when compared to the control (without Al). At $100 \mathrm{mg} \mathrm{kg}^{-1} \mathrm{Al}$ concentration, the shoot's dry mass production decreased, although the values did not differ from 0 and $25 \mathrm{mg} \mathrm{kg}^{-1} \mathrm{Al}$ treatments. The values of the shoot's dry mass were higher in the TSP when compared to the WP or in AP source, at least up to $50 \mathrm{mg} \mathrm{kg}^{-1} \mathrm{Al}$ concentration (Fig. 1A). A similar behavior was shown in the response of triticale plants to the $\mathrm{Al}$ concentration in the sand substrate using TSP as a P source (Quartin et al., 2001) and in a clayey soil cultivated with the corn (Pintro et al., 2004). It should be noted that the shoot's dry mass value 
was significantly higher at $\mathrm{Al} 50 \mathrm{mg} \mathrm{kg}^{-1}$ in the AP source than without $\mathrm{Al}$ and at $100 \mathrm{mg} \mathrm{kg}^{-1} \mathrm{Al}$ treatments. A positive interaction between the $\mathrm{P}$ from the AP and $\mathrm{Al}$ in the above $\mathrm{P}$ source increased the shoot's dry mass production (Fig. 1A). Salvador et al. (2000) showed that, when the
$\mathrm{Al}$ in the nutrient solution ranged from 5 to $10 \mathrm{mg}$ $\mathrm{kg}^{-1}$, the growth and development of the guava plants were higher than in the control (without $\mathrm{Al}$ ) and when the $\mathrm{Al}$ concentrations ranged from 20 to $25 \mathrm{mg} \mathrm{kg}^{-1}$.

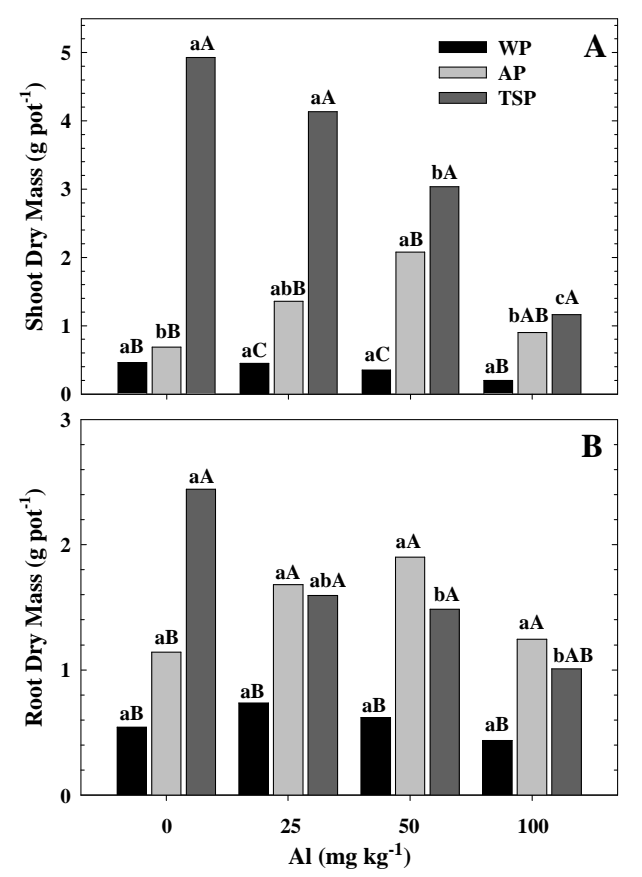

Figure 1 - Dry mass of corn plants (A - shoot and B - roots) cultivated using different commercial phosphate fertilizers and aluminum concentrations. Means followed by the same uppercase letter indicate no significance at $5 \%$ of probability (Tukey test) between phosphate sources and for each Al concentration value. Means followed by the same lower-case letter indicate no significance at $5 \%$ of probability (Tukey test) between Al concentration values and for each phosphate source. (WP - without P; AP - Arad phosphate; TSP - Triple superphosphate).

The increase in the shoot and dry matter production in the $\mathrm{Al} 25$ to $50 \mathrm{mg} \mathrm{kg}^{-1}$ doses could partially be explained by the steady and increasing $\mathrm{P}$ availability by the AP source which protected the cell's membrane against the $\mathrm{Al}$ toxic actions. The AP source could be another possibility, different than the TSP source, which would gradually and continuously be bound to the $\mathrm{Al}$ and precipitate it.

Fig. 1B show results of the root's dry mass production. When the $\mathrm{Al}$ concentration increased, the shoot's dry mass production was significantly and continuously reduced only at the TSP source. Other P sources failed to present the same negative influence on the values of the root's dry mass. The highest values for the root dry mass were reported in the TSP source and without $\mathrm{Al}$ treatment. As the
Al concentration increased, the root's dry mass production decreased significantly. The dry mass root production for the AP and TSP treatments were not statistically different $(P>0.05)$ with 25 and 50 $\mathrm{mg} \mathrm{Al} \mathrm{kg}{ }^{-1}$ substrate, i.e., these $\mathrm{P}$ sources made available similar $\mathrm{P}$ concentrations in the solution. Similar behavior was not observed in the clayey tropical soils (Novais and Smyth, 1999; Pintro et al., 2004) due to the formation of inner sphere complexes between the iron and aluminum oxides and phosphorus. Rheinheimer et al. (1994) and Pintro et al. (1996), also recorded the reduction in the root's dry mass due to the $\mathrm{Al}$ toxicity.

Figure 2 shows the distribution of the total dry mass production of the corn plants, a function of the $\mathrm{P}$ sources and $\mathrm{Al}$ concentrations. When the $\mathrm{Al}$ concentration increased, the values of the total dry 
mass decreased significantly only in the TSP source, more specifically in the $100 \mathrm{mg} \mathrm{kg}^{-1} \mathrm{Al}$ concentration. The contribution of roots and shoot (in relative values) to the total dry mass was influenced by the $\mathrm{P}$ sources and $\mathrm{Al}$ concentration in the substrate (Fig. 2).

When the $\mathrm{Al}$ concentration increased in the WP treatment, an increase was noted in the root participation (in relative values) in the total dry mass, with values ranging from 54 to $69 \%$ (Fig. 2A). This might have occurred because the root grown without $\mathrm{P}$ might have minor protection against the $\mathrm{Al}$ at the membrane level, since $\mathrm{P}$ was important for the structural integrity of the phospholipids in the membrane. The increase of the root's dry mass may, in this case, denounced greater $\mathrm{Al}$ damage, or rather, the $\mathrm{Al}$ activity could cause higher thickening rates to the radical and, consequently, greater total root weight. This meant that there was an increase in the root/shoot ratio in proportion to an increase in the $\mathrm{Al}$ concentration in the solution. In the TSP source, the total dry mass production was significantly reduced by increasing the $\mathrm{Al}$ concentrations. It was important to note that in this P source (TSP) the contribution of the root values was lower than $50 \%$ of the total dry mass values (Fig. 2B). The opposite occurred in the WP treatment (Fig. 2A). In the AP source, the total dry mass increased when the $\mathrm{Al}$ concentration ranged from 0 to $50 \mathrm{mg} \mathrm{kg}^{-1}$ and decreased by $46 \%$ when the $\mathrm{Al}$ ranged from 50 to $100 \mathrm{mg} \mathrm{kg}^{-1}$ (Fig. 2C).

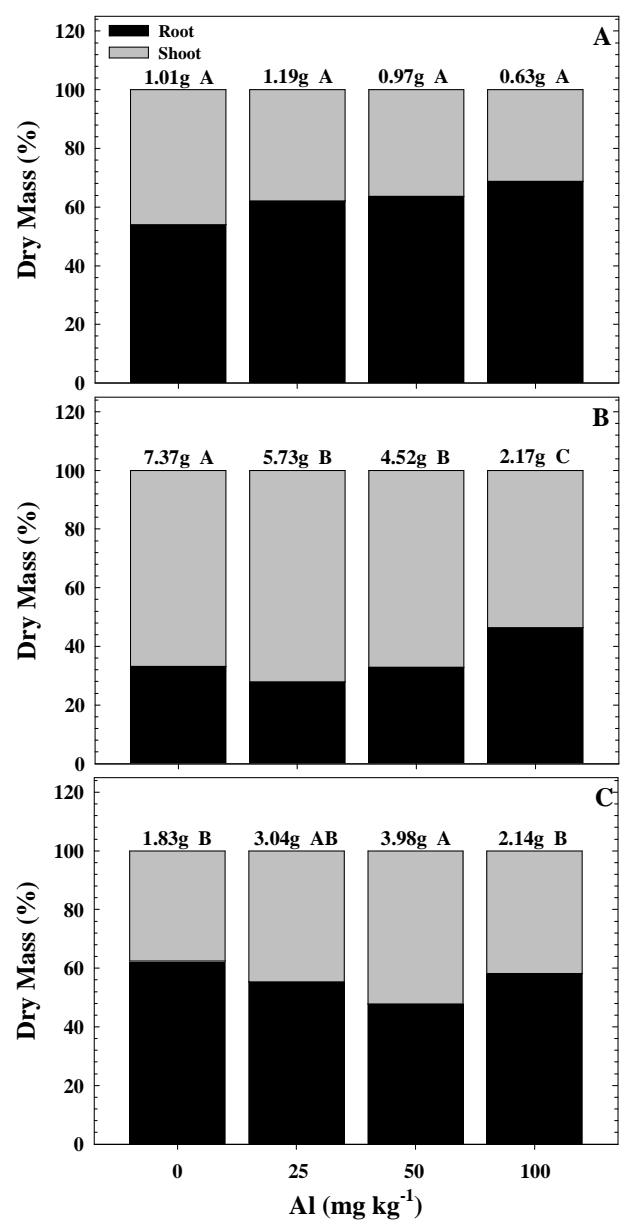

Figure 2 - Distribution of the total dry mass of corn plants cultivated for 35 days using different sources of $\mathrm{P}$ and $\mathrm{Al}$ concentrations. Means followed by the same upper-case letter indicate no significance at $5 \%$ of probability (Tukey test) between Al concentration values in the same source of P. (A. Without P - WP; B. Triple Superphosphate - TSP; C. Arad phosphate - AP). 
The values of the root participation in the total dry mass were higher than $50 \%$, very similar to that reported in the WP treatment (Fig. 2A). The rates of the root participation were lower than $50 \%$, but only at $50 \mathrm{mg} \mathrm{kg}^{-1}$ of Al. Results of the current investigation were different from those obtained by Zanata and Mundstock (1988), where the participation of the wheat roots in the total dry mass decreased when the $\mathrm{Al}$ concentration increased.

Phosphorus availability in the substrate of the AP source determined by Mehlich-1 extractor (Table 1) did not result in high $P$ values in the shoot of the corn plant (Table 2) and in the dry mass production (Fig. 2C). Faria and Albuquerque (1989) observed that the Mehlich-1 extractor was not an appropriate method to evaluate the $\mathrm{P}$ availability to a buffel-grass pasture in the semiarid northeastern Brazil, where partially acidulated phosphate was used as a P source. Conversely, it seemed that in the TSP source, a good correlation existed between the $\mathrm{P}$ availability in the substrate (Table 1), $\mathrm{P}$ values in the shoot of the corn plant (Table 2) and the total dry mass production (Fig. 1 and 2B).

In proportion to the increases in the $\mathrm{Al}$ concentration, the total dry mass of the corn plant decreased when the TSP source was used. On the other hand, when the AP source was taken into account, an increase in the total dry mass values occurred when the $\mathrm{Al}$ concentration ranged from 0 to 25 and $50 \mathrm{mg} \mathrm{kg}^{-1}$. Although the values of the total dry mass in the AP source were lower than those in the TSP source, in relative terms, there was a positive interaction between the AP and $\mathrm{Al}$, reducing the $\mathrm{Al}$ activity (i.e. its toxicity) up to 50 $\mathrm{mg} \mathrm{kg}{ }^{-1}$. Within this range ( 0 to $50 \mathrm{mg} \mathrm{kg}^{-1}$ ), no negative influence on the dry mass production was reported, as was observed in the TSP source.

In studies that involved the $\mathrm{Al}$ toxicity and $\mathrm{P}$, the $\mathrm{Al}$ concentrations and $\mathrm{P}$ sources should be also taken into account. In this study, the TSP source decreased the shoot and root dry mass production with the increasing $\mathrm{Al}$ concentration, while the $\mathrm{AP}$ source did not present similar behavior.

\section{ACKNOWLEDGMENTS}

The financial support given by CNPq (Conselho Nacional de Pesquisa e Desenvolvimento), Brasília, DF, Brazil is appreciated.

\section{RESUMO}

Foram avaliadas plantas de milho submetidas a diferentes fontes de fertilizantes fosfatados e diferentes concentrações de alumínio em um substrato de areia. $\mathrm{O}$ experimento foi conduzido com duas plantas por vaso contendo $2 \mathrm{~kg}$ de areia, duas fontes de fósforo (Fosfato Supertriplo - TSP ou Fosfato de Arad - AP) e quatro concentrações de Al. Com o aumento das concentrações de $\mathrm{Al}$ houve diminuição dos valores de $\mathrm{pH}\left(\mathrm{CaCl}_{2}\right)$ do substrato. Os valores de cálcio e fósforo aumentaram no substrato nos tratamentos com TSP e AP. As concentrações de cálcio, magnésio, fósforo e de potássio das plantas de milho foram maiores em TSP do que nos tratamentos sem $\mathrm{P}$ ou com AP. Como o aumento da concentração de Al observou-se redução na concentração de cálcio, magnésio, fósforo e de potássio nas plantas. A produção de massa seca da parte aérea respondeu positivamente com as fontes de P. Com o aumentou da concentração de $\mathrm{Al}$ os valores de massa seca diminuíram significativamente com TSP.

\section{REFERENCES}

Adrew, C.S.; Berg, P.J.V. (1973), The Influence of aluminum on phosphate adsorption by whole plants and excised roots of some pasture legumes. Aust. J. Agric. Res., 24, 341-351.

Alva, A.K.; Edwards, D.G.; Asher, C.J.; Blamey, F.P.C. (1986), Effects of phosphorus/aluminum molar ratio and calcium concentration on plant response to aluminum toxicity. Soil Sci. Soc. of Am. J., 50, 133137.

Calbo, A.G.; Cambraia, J. (1980), Efeito do alumínio sobre a composição mineral de dois cultivares de sorgo (Sorghum bicolor L. Moench). Rev. Ceres, 27, 369-378.

Camargo, C.E.O. (1985), A concentração de fósforo na tolerância de cultivares de trigo à toxicidade de alumínio em soluções nutritivas. Bragantia, 44, 4964.

Chien, S.H.; Menon, R.G. (1995), Factors affecting the agronomic effectiveness of phosphate rock for direct application. Fertilizer Research, 41, 227-234.

Coamo. (1998), Fertilidade do solo e nutrição de plantas. Coamo/Coodetec. Campo Mourão, PR, Brasil.

Costa, A.; Campos, L.A.C.; Riede, C.R. (2003), Reaction of wheat genotypes to soil aluminum differential saturations. Braz. Arch. Biol. Technol., 46, 19-25. 
Embrapa. (1999), Manual de análises químicas de solos, plantas e fertilizantes. Embrapa, Brasília, DF, Brasil.

Ernani, P.R.; Steckling, C; Bayer, C. (2001), Características químicas de solo e rendimento de massa seca de milho em função do método de aplicação de fosfatos, em dois níveis de acidez. Rev. Bras. de Ci. Solo, 25, 939-946.

Faria, C.M.B.; Albuquerque, S.G. (1989), Fosfato parcialmente solubilizado em pastagem de capimbúfel no submédio São Francisco. Rev. Bras. de Ci. Solo, 13, 393-397.

Fleming, A.L. (1983), Amonnium upatke by wheat varieties differing in Al tolerance. Agron. J., 75, 726730.

Goedert, W.J.; Souza, D.M.G. (1984), Uso de fertilizantes fosfatados. In-Simpósio sobre fertilizantes na agricultura brasileira. Brasília, ed. Espinoza, W; Oliveira, A.J. de. DF, 06-10 agosto 1984. EMBRAPA-DID, Brasília, DF. (Documentos, 14), pp. 255-290.

Hartwell, B.L.; Pember, F.R. (1918), The presence of aluminum as a reason for the difference in the effect of so-called acid soil on barley and rye. Soil Sci., 6, 259-281.

Helyar, K.R. (1978), Effects of aluminum and manganese toxicity on legume growth. In. Mineral nutrition of legumes in tropical and subtropical soils, ed. Andrew, C.S.; Kamprath, E.J.; CSIRO, Melborne, Australia, pp. 207-231.

Khasawneh, F.E.; Doll, E.C. (1978), The use of phosphate rock for direct application to soils. $A d v$. Agr., 30, 159-206.

Macklon, A.E.S.; Sim, A. (1992), Modifying effects of a non-toxic level of aluminum on phosphate fluxes and compartmentation in root cortex cells of intact ryegrass seedlings. J. Exp. Bot., 43, 1483-1490.

Magistad, O.C. (1925), The aluminum content of the soil solution and its realtion to soil reaction and plant growth. Soil Sci., 20, 181-227.

Malavolta, E. (1981), Manual de química agrícola: Adubos e Adubação. Editora Agronômica Ceres Ltda, São Paulo, Brasil.

Malavolta, E.; Vitti, G. C.; Oliveira, S. A. de. (1997), Avaliação do estado nutricional das plantas: princípios e aplicações. POTAFÓS, Piracicaba.

Matsumoto, H.; Morimura, S. (1980), Repressed template activity of chromatin of pea roots treated by aluminum. Plant Cell Physiol., 21, 951-959.

McCormick, L.H. (1974), The occurrence of aluminum phosphate precipitate in plant roots. Agron. J., 38, 931-934.

McCormick, L.H.; Borden, F.Y. (1972), Phosphate fixation by aluminum in plant roots. Soil Sci. Soc. Am. Proc., 36, 799-802.
Novais, R. F. de; Neves, J. C. L.; Barros, N. F. de. (1991), Ensaio em ambiente controlado. In-Métodos de Pesquisa em Fertilidade do Solo, ed. Oliveira, A. J. de; Garrido, W. E.; Araujo, J. D. de; Lourenço, S. Brasília: EMBRAPA-SEA, 189-253.

Novais, R. F.; Smyth, T. J. (1999), Fósforo em solo e planta em condições tropicais. UFV, Viçosa.

Pavan, M.A.; Binghan, F.T. (1982), Toxidez de alumínio em cafeeiros cultivados em solução nutritiva. Pesq. Agropec. Bras., 17, 1293-1302.

Pintro, J.; Barloy, J.; Fallavier, P. (1996), Aluminum effects on the growth and mineral composition of corn plants cultivated in nutrient solution at low aluminum activity. J. Plant Nutr., 19, 729-741.

Pintro, J.C.; Inoue, T.T., Tormena, C.A., Costa, A.C.S.; Silva, M.A.G. (2004), Mineral composition and dry mass production of corn plants affected by different phosphate sources and different soil aluminum saturation levels. J. Plant Nutr., 27, 2149-2158.

Quartin, V.L.; Azinheira, H.G.; Nunes, M.A. (2001), Phosphorus deficiency is responsible for biomass reduction of triticale in nutriente solution with aluminum. J. Plant Nutr., 24, 729-741.

Rajan, S.S.S.; Watkinson, J.H.; Sinclair, A.G. (1996), Phosphate rocks for direct application to soils. $A d v$. Agr., 57, 78-159.

Randall, P.J.; Vose, P.B. (1963), Effect of aluminum on uptake and translocation of phosphorus by perennial ryegrass. Plant Physiol., 38, 403-409.

Rheinheimer, D.S.; Petry, C.; Kaminski, J.; Bartz, H.R. (1994), Influência do estresse de alumínio em plantas de fumo: I. Efeito no sistema radicular, na absorção de fósforo e cálcio e no acúmulo de massa seca. Rev. Bras. de Ci. Solo, 18, 63-68.

Roy, A.K.; Sharma, A.; Talukder, G. (1994), Some aspects of aluminum toxicity in plants. Bot. Rev., 54, 145-177.

Salvador, J.O.; Moreira, A.; Malavolta, E.; Cabral, C.P. (2000), Influência do alumínio no crescimento e na acumulação de nutrientes em mudas de goiabeira. Rev. Bras. de Ci. Solo, 24, 787-796.

Sanchez, P.A.; Salinas, J.G. (1981), Low input technology for managing Oxisols and Ultisols in tropical America. Adv. Agr., 34, 280-406.

SAS Institute (1991), SAS/STAT procedure guide for personal computers. 5. ed. SAS Inst., Cary, N. C.

Zanata, A.C.A.; Mundstock, C,M, (1988), Efeito dos níveis de fósforo e alumínio sobre os sistemas aéreo e radicular do trigo. Pesq. Agropec. Bras., 23, 13551370 .

Received: March 08, 2007; Revised: August 06, 2007; Accepted: July 23, 2008. 